\title{
Capacity building for conservation: problems and potential solutions for sub-Saharan Africa
}

\author{
M. J. O’Connell, O. Nasiria, M. Carter, K. H. Farmer, M. Appleton \\ J. Arinaithe, P. Bhanderi, G. Chimbaza, J. Copsey, J. Dodoo, A. Duthie \\ M. Gachanja, N. Hunter, B. Karanja, H. M. Komu, V. Kosgei, A. Kuria \\ C. Magero, M. Manten, P. Mugo, E. Müller, J. Mulonga, L. Niskanen \\ J. Nzilani, M. Otieno, N. Omen, J. Owuor, S. Paterson, S. Regnaut, R. Rono \\ J. Ruhiu, J. Theuri Njoka, L. Waruingi, B. Waswala Olewe and E. Wilson
}

\begin{abstract}
To achieve their conservation goals individuals, communities and organizations need to acquire a diversity of skills, knowledge and information (i.e. capacity). Despite current efforts to build and maintain appropriate levels of conservation capacity, it has been recognized that there will need to be a significant scaling-up of these activities in sub-
\end{abstract}

M. J. O’Connell (Corresponding author) ERT Conservation, 4 Peghouse Rise, Stroudmanag, GL5 1RT, UK. E-mail mark@ert-conservation.co.uk

O. Nasirwa National Museums of Kenya, Nairobi, Kenya, and OONA Development Consultants Limited, Nairobi, Kenya

M. Carter, A. Duthie and S. Paterson Fauna \& Flora International, Cambridge, UK

K. H. FARMER Faculty of Natural Sciences, University of Stirling, Stirling, Scotland

M. Appleton, International Consultant, Thetford, UK

J. Arinaitwe, C. Magero and M. Manten BirdLife International Africa Partnership Secretariat, Nairobi, Kenya

P. BhANDERI and J. Mulonga Wetlands International, Nairobi, Kenya

G. ChimwaZA Information Training \& Outreach Centre for Africa, Centurion, South Africa

J. Copsey Durrell Wildlife Conservation Trust, Trinity, Jersey, Channel Islands, UK

J. Dodoo, H. M. Komu*, J. Theuri Njoka and B. Waswala Olewe $\dagger$ University of Nairobi, Nairobi, Kenya

M. Gachanja, N. Hunter and R. Rono East African Wild Life Society, Nairobi, Kenya

B. Karanja African Wildlife Foundation, Nairobi, Kenya

V. Kosgei and J. NziLani Fauna \& Flora International, Nairobi, Kenya

A. Kuria, P. Mugo and J. Owuor Tropical Biology Association, Nairobi, Kenya

E. MÜLLER University for International Cooperation, San Jose, Costa Rica

L. Niskanen IUCN, Nairobi, Kenya

M. OTIEno Kenyatta University, Nairobi, Kenya

N. OwEn Zoological Society of London, London, UK

S. Regnaut IUCN, Ouagadougou, Burkina Faso

J. RuHiu Community Development Trust Fund, Nairobi, Kenya

L. Waruingi African Conservation Centre, Nairobi, Kenya

E. WiLSON Well Grounded, London, UK

*Also at: Kenya Forestry Research Institute, Nairobi, Kenya $\dagger$ Also at: United Nations Environment Programme, Nairobi, Kenya

Received 7 November 2016. Revision requested 9 December 2016.

Accepted 13 February 2017. First published online 1 June 2017.
Saharan Africa. This is because of the rapid increase in the number and extent of environmental problems in the region. We present a range of socio-economic contexts relevant to four key areas of African conservation capacity building: protected area management, community engagement, effective leadership, and professional e-learning. Under these core themes, 39 specific recommendations are presented. These were derived from multi-stakeholder workshop discussions at an international conference held in Nairobi, Kenya, in 2015. At the meeting 185 delegates (practitioners, scientists, community groups and government agencies) represented 105 organizations from 24 African nations and eight nonAfrican nations. The 39 recommendations constituted six broad types of suggested action: (1) the development of new methods, (2) the provision of capacity building resources (e.g. information or data), (3) the communication of ideas or examples of successful initiatives, (4) the implementation of new research or gap analyses, (5) the establishment of new structures within and between organizations, and (6) the development of new partnerships. A number of cross-cutting issues also emerged from the discussions: the need for a greater sense of urgency in developing capacity building activities; the need to develop novel capacity building methodologies; and the need to move away from onesize-fits-all approaches.

Keywords Africa, capacity building, community engagement, e-learning, leadership, protected area management

\section{Introduction}

The biological diversity of sub-Saharan Africa (and asso1 ciated islands) is under pressure from a range of anthropogenic activities, and it is widely accepted that the ongoing loss of species and habitats requires concerted and coordinated action across the region (Stuart \& Adams, 1990; Craigie et al., 2010; Beresford et al., 2013; BirdLife International, 2013; Perrings \& Halkos, 2015; UNEP-WCMC, 2016). To address changes to sub-Saharan environments and biodiversity, a large number of local, national and international conservation plans have been 
produced. These often contain detailed goals and time-bound targets (Secretariat of the Convention on Biological Diversity, 2014; Ozor et al., 2016). However, delivering these plans requires a wide range of diverse skills, knowledge and information to achieve the stated objectives. Collectively, these elements are often called capacity, and the process of acquiring them is called capacity building. However, an agreed definition of the capacity building concept remains elusive for the conservation sector, and there are a large number of terms and definitions used by various individuals and organizations (e.g. capacity development, competency, capability). A discussion of these various terms is beyond the scope of this paper, but comprehensive overviews are provided by Whittle et al. (2012) and Appleton (2015). Here, a working concept of capacity building is used, which largely follows the UN's approach of focusing on 'the combination of all the strengths, attributes and resources available within a community, society or organization that can be used to achieve agreed goals' (UNISDR, 2016).

Beyond attempts to pin down a definition, the key capacity issue for conservation in Africa is that few of the multitude of plans to halt and reverse the loss of biodiversity include a qualitative and quantitative assessment of the capacity required for the successful delivery of stated aims. To discuss the ongoing issue of capacity building for conservation and natural resource management, 185 delegates representing 105 organizations from 24 African nations and eight non-African nations met in Nairobi, Kenya, in 2015. These practitioners, scientists, community groups and government agencies used a framework of four main themes (outlined below) to discuss methods for the acquisition and long-term maintenance of skills, knowledge, information and competencies within the conservation sector. However, any discussion of capacity building also needs to recognize the large number of associated issues that can alter the scope and extent of impact in various contexts, including local/national facilitating environments, levels of available funding, public awareness and attitudes, and the required scale of impact. These issues therefore formed the cross-cutting themes of the meeting and a background perspective for the key recommendations from each thematic workshop. We provide an overview of the broad thematic backgrounds to the four workshops, and report the key discussions and recommendations made during the 4 -day meeting.

\section{African contexts for conservation and resource management}

Sub-Saharan Africa is one of the most biodiverse regions on Earth, with $>100,000$ species of insects, 50,000 plants, 1,100 mammals, 2,355 birds, 3,000 freshwater fishes, 950 amphibians and 1,600 reptiles (Stuart et al., 2004; UNEP, 2010; Myers et al., 2012; Han et al., 2016). Five of the world's biodiversity hotspots, 373 Ramsar sites and $>1,250$ Important Bird and Biodiversity Areas are in Africa, and many taxonomic groups contain relatively large proportions of endemics (Mittermeier et al., 2011; BirdLife International, 2013). Patterns of species diversity in the region generally follow latitudinal gradients, and the equatorial tropical forests are amongst the most productive natural systems in the world (net primary productivity of $>800 \mathrm{~g} \mathrm{C} \mathrm{m}^{-2} \mathrm{yr}^{-1}$; Pan et al., 2015). Africa also has an extensive network of protected areas $\left(>_{2}\right.$ million $\left.\mathrm{km}^{2}\right)$, covering c. $10 \%$ of the 119 recognized African ecoregions (WWF, 2016).

Despite this considerable natural capital, when measured across a range of socio-economic metrics, Africa is the world's poorest region. In the 21st century it is predicted to have the largest population growth of any continent, and all of the 10 nations with the highest fertility rates are in sub-Saharan Africa. Forty-three percent of the region's population is $<15$ years of age (He et al., 2016). The human population is currently 1.1 billion, and this will increase to at least 2.4 billion by 2050 (assuming that family planning initiatives achieve targets for declines in the birth rate of key countries). These population increases are not predicted to be accompanied by economic growth that will lead to a proportional increase in employment or governmental investment in infrastructure and resilience (UNDESAPD, 2015). The predicted outcome of this population increase is further extensive land-use change (agricultural conversion) accompanied by increased direct/indirect impacts on natural resources (e.g. soil erosion and degradation, loss of biodiversity, habitat fragmentation, loss of ecosystem services). Pressures on water resources (and associated wetland biodiversity) are also predicted to increase, with many watersheds suffering from over-abstraction, pollution and degradation (McKee et al., 2004). Over the next century these pressures will be exacerbated by the impacts of climate change. The region is particularly vulnerable to climate alteration as a result of agricultural practices that rely on rainwater and that lack drought resilience. Per capita access to land is low in many African countries, and the Food and Agriculture Organization of the United Nations predicts that population growth will result in an additional 36 million Africans being affected by droughtrelated famine by 2050 (Bruinsma, 2009; Turral et al., 2011). It is in this context of ongoing social, economic and land use changes that African government agencies, conservation organizations, civil society organizations, and local community groups must develop strategies, policies and actions to ensure a sustainable future for people, wildlife and natural systems. 


\section{Responses to environmental issues in Africa}

Conservation responses to pressures on African biodiversity and natural capital occur at a number of nested operational and ecological scales. Many conservation organizations and agencies work across these scales (communities to international). However, this can have implications for how they set priorities, their operational costs, and the reach, impact and sustainability of their actions. These scale effects are also present in considerations of capacity building, and there is a considerable need for research to measure the relative cost-effectiveness and impact of conservation actions implemented at various levels and scales (Henson et al., 2009; Guerrero et al., 2013). At the international level, transboundary issues and actions have always been a feature of African conservation. Most sub-Saharan nations have signed up to the key multilateral environmental agreements, and efforts are being made to integrate these with national legislation and administrative frameworks. This includes harmonizing capacity building efforts across the various conventions (Jones, 2003; Steiner et al., 2003; Burnside \& Dollar, 2004; Ambalam, 2014; Ozor et al., 2016).

Since the 1990s, in many sub-Saharan countries there has been an increase in the number of tertiary education establishments offering applied courses associated with biodiversity, conservation, sustainable development and community engagement (World Bank, 2009; Vasudev et al., 2015), as well as in the provision of environmental e-learning in Africa (Aderinoye et al., 2009). E-learning has the potential to provide accessible, strategic, low-cost and efficient means to build capacity in some areas of conservation. However, despite the rapid increase in the availability of both face-to-face and e-learning courses, it is clear these need to be driven pro-actively by strategic partnerships between the conservation and education sectors. Research is also needed to measure and evaluate the conservation impacts of various delivery methods.

At the same time as multilateral environmental agreements and tertiary education have been responding to environmental change, there has also been a major grass-roots response (Lewis, 2002). This has been led largely through community-based conservation and the rise of African civil society organizations, which now play an important role in catalysing positive local-level changes that improve natural resource management and the conservation of biodiversity (Armitage, 2005; Maliasili Initiatives \& Well Grounded, 2015).

The other major response to environmental change in Africa that spans all operational and spatial scales is research. For much of the past 50 years there has been a considerable effort to describe, understand and predict changes to the components and functioning of natural systems. Sometimes this has been undertaken by external organizations, often in partnership with African bodies. More recently, African institutions have been building their own research capacity through the employment of dedicated research staff. However, as with conservation research elsewhere, there remains a gap between the provision of knowledge and its use in developing conservation actions. The difficulties associated with improving the use of research by African conservation organizations have been known for many years (Lampietti \& Subramanian, 1995) but have yet to be fully resolved (Western, 2003).

\section{Capacity implications for the African conservation community}

The key implication arising from the extent, severity and speed of environmental change in Africa is the need to deliver cost-efficient, strategic, evidence-based, sustainable, equitable and adaptive capacity building across the conservation sector. This is coupled with widely varying facilitating environments across sub-Saharan Africa (and its associated islands). These internal (organizational) and external contexts (environmental, cultural and socioeconomic) change the nature and emphasis of capacity building needs, and how provision may be evaluated. Even ignoring contextual effects, the general efficacy of more established capacity building methods (e.g. training, tertiary education, mentoring) has also yet to be fully evaluated (Wilder \& Walpole, 2008; Washington et al., 2015). In the meantime, the sector is trying to broaden the range of methods used; for example, competence-based techniques developed in the 1980s (Burke, 1989) have been applied recently to building capacity for protected area managers. The approach identifies core professional requirements (competencies) for staff at various organizational levels and in various roles (IUCN, 2015; Müller et al., 2015). Advocates of competence-based approaches suggest that they could help overcome the problems associated more with the established capacity building methods. In particular, identifying competencies with specific professional roles is both proactive and strategic, rather than merely reacting to capacity needs as they arise. This also facilitates the raising of professional standards, and harmonization across the sector. Nevertheless, despite other sectors (notably public health) having accepted and adopted these approaches, the efficacy of competence-based approaches in conservation has yet to be evaluated (Brightwell \& Grant, 2013).

It was the need to discuss and generate solutions to the broad spectrum of individual and organizational issues and contexts associated with conservation capacity building that led to the development of the conference in Nairobi in 2015.

\section{Conference development}

The 2015 Nairobi conference was developed explicitly to provide a forum for key organizations in sub-Saharan Africa to 
discuss capacity building issues. The thematic areas for the meeting were developed originally by the conference secretariat and an independent panel of conservation and capacity experts. These four core generic themes built on discussions at the first regional conservation capacity building conference held in Colombia in 2013: (1) capacity for protected area management, (2) community engagement and rights-based governance, (3) effective leadership and strong organizations, and (4) professional e-learning.

An African committee was then established, with representation from 14 organizations. The remit of the committee was to render the core generic themes into focused discussion areas relevant within specifically African contexts, and to select speakers for each sub-thematic area. The need for a definite output from the conference was also discussed at this stage. It was agreed within the committees that there would be a session at the meeting focusing on developing a post-conference community of practice. The sections below provide an overview of the key discussion points and recommendations arising from each workshop in the four thematic areas.

\section{Thematic area 1: capacity building to support protected area management}

Protected areas in Africa play a critical role in the conservation and management of some of the most diverse terrestrial and marine sites in the world (Stolton \& Dudley, 2010; Bertzky et al., 2012). Their effective management provides an opportunity for close inter-institutional coordination, synergies between local and national initiatives, and increased understanding of the values of protected areas by a range of communities and stakeholder groups (Kothari et al., 2012; Müller et al., 2015; Barnes et al., 2016). Protected areas can also be designed and managed to alleviate poverty for communities living within and around their boundaries and to enhance community-based decision making (Borrini-Feyerabend et al., 2013). However, according to a global assessment in 2010 only $17 \%$ of 644 African protected areas assessed were under 'sound management', $31 \%$ had 'basic management', $31 \%$ had 'basic management but major deficiencies', and $21 \%$ were 'clearly inadequate' (Leverington et al., 2010a). It is therefore essential that organizations responsible for protected area management in Africa have a clear understanding of the capacity needed to fulfil the increasingly complex goals of these areas, as well as a quantified assessment of gaps in the competencies of their core staff. Since the 199os there has been a lag between the development of methods for identifying the capacity needs of protected area staff, compared to the number of initiatives focused on metrics to measure protected area management effectiveness (Leverington et al., 2010b). Assessments of protected area management effectiveness focus on management elements such as planning and adaptive feedback mechanisms but are not always able to measure capacity gaps directly (Coad et al., 2015). The IUCN guidance on protected area management effectiveness stresses that data should be used to identify 'the extent to which measured outcomes are due to management interventions or to other factors which may be beyond a manager's control' (Hockings et al., 2006). Competency evaluations as part of protected area capacity building initiatives therefore constitute a complementary tool to protected area management effectiveness assessments for achieving conservation goals.

\section{Thematic area 2: community engagement and rights-based governance}

The majority of sub-Saharan African countries have large rural societies, with communities making their living through agriculture, pastoralism or the use of forests and wild products. These livelihoods are therefore strongly linked to the sustainable management of water, soils and forest products, as well as the conservation of the species and habitats within associated ecosystems. Although the effective management and conservation of natural systems and the resources they provide are the concern and responsibility of all citizens of a country, the consequences of environmental degradation (and subsequent conservation or management actions) are experienced locally. This motivates action based on local knowledge (ecological, social and cultural), and community-based decisions that have greater relevance and are based on rapid reporting of changes in biodiversity or threats.

Local communities must therefore be fully engaged in conservation actions and resource management. Often, however, communities do not derive socio-economic or livelihood benefits from environmental stewardship, nor do they have an equitable voice in decision making and policy development processes that affect their well-being and livelihoods (Agrawal \& Gibson, 1999; Maathai, 2009). African governments, which are all signatories to the African Charter on Human and Peoples' Rights (the African Charter), must respect human rights in all areas relating to natural resource governance, and develop a clear legal framework to deliver these rights. This is as a result of a resolution adopted in 2012 by the African Commission on Human and Peoples' Rights, in the context of the Rio+20 Conference (Rio+20 Portal, 2016). The Commission noted how 'natural resources governance is often hampered by illplanned development, misappropriation of land, corruption, bad governance, and prevailing insecurities.' It also noted how communities in Africa 'continue to suffer disproportionally from human rights abuses in their struggle to assert their customary rights to access and control various resources, including land, minerals, forestry and fishing.' 
The role of women in resource governance and civil society organizations was also recognized by the Commission because women can often be sidelined from the community and regional decision-making processes that affect them (FAO, 2011). Although the core concepts of community engagement and rights-based governance are mainstreamed into African legal frameworks and local governance actions, there is still a long way to go in building the requisite capacity of local communities. A transnational survey of $>70$ leading African civil society organizations, international organizations, funders and organizational development experts (Maliasili Initiatives \& Well Grounded, 2015) found that African civil society organizations play a central role in catalysing positive changes in natural resource governance and conservation; face significant challenges in their efforts to build the capacity to sustain their impact; need evidence of the impacts of capacity building and organizational strengthening; often have their operational focus skewed by external influences (partners), in the absence of strong leadership; and can have capacity building aims related to compliance with contractual obligations to funders. There is therefore an urgent need for continued efforts and research on effective community engagement and good practice in capacity building for civil society organizations in key areas.

\section{Thematic area 3: effective leadership and strong organizations}

Strong, committed and highly skilled leaders are a crucial element in an organization or community's ability to achieve its stated goals. Strong organizations have the ability to assess internal needs, plan and implement organizational development goals, and measure their progress using tangible metrics and indicators. Leaders must therefore be able to develop and maintain the operational efficiency and resilience of their organizations through building appropriate organizational structures, strategies, accountability and finances. Despite the acknowledged role of leadership in conservation, the sector has been relatively slow to adopt evidence-based models of good leadership practices from other sectors (Manolis et al., 2009). There have been attempts to bring greater clarity and definition to what is actually meant by leadership in various conservation contexts (Bruyere, 2015).

A key starting perspective for the development of leaders is the characterization of good and bad leadership traits in a range of situations and working environments (Black et al., 2011). However, as a result of extensive management research in the 1970s it has been accepted that leadership is defined as much by behaviours and strategies as by the particular traits and interpersonal qualities of individuals (Senge, 2006), and leadership development cannot be viewed as a single regular choice. It is therefore vital that conservation organizations and communities think carefully about succession planning and career structures, and identify, support and develop future leaders at all levels of an organization. This approach is key to facilitating creative and effective engagement with challenging issues and limited resources.

\section{Thematic area 4: professional e-learning}

E-learning is defined as learning that utilizes the internet and associated electronic technologies to access an educational curriculum outside traditional classroom (face-to-face) learning. Despite problems with internet access in some areas, electrification of rural areas and the wider information and communications technology network are expanding and improving rapidly. A survey identified significant factors constraining information and communications technologyenhanced learning in 41 African countries (Shafika \& Hollow, 2012). The key constraining factor was found to be limited bandwidth, followed by the lack of financial resources, inadequate human resource capacity and limited electricity. Nonetheless, information and communications technologyenhanced e-learning is being embraced by higher-learning institutions in Africa. Freely available online e-learning has the potential to provide continued professional development for a wide range of individuals and conservation organizations. Online training and knowledge exchange platforms facilitate much-needed scaling up of effort to complement more established delivery methods (e.g. attendance at courses). They also have the ability to reach professional end-users who live in remote areas, have limited financial resources, and need to access training material throughout their professional life (not just during a course).

\section{Discussion}

Thirty-nine recommendations were developed at the conference (Tables 1-4), with six broad types of suggested action: (1) the development of new methods, (2) the provision of capacity building resources (e.g. information or data), (3) the communication of ideas or examples of successful initiatives, (4) the implementation of new research or gap analyses, (5) the establishment of new structures within and between organizations, and (6) the development of new partnerships.

For these recommendations to deliver real impact and change they will need to be communicated, interpreted and assimilated into existing frameworks. In particular, in developing these recommendations, conference delegates recognized the need for follow-up and collaboration in the form of a community of practice. A subset of attendees committed to developing a range of post-conference activities and funding applications to deliver tangible outcomes in the longer term. Given the time taken to establish and 
TABLE 1 Key discussions and recommendations in relation to the building of capacity to support the management of protected areas in sub-Saharan Africa.

Key discussion points

African protected area organizations face capacity building challenges at the individual, organizational \& societal levels.

Professionalization is a key area of capacity building for protected area organizations. Protected area management must be recognized as a profession, with its own standards, systems \& tools.

The IUCN World Commission on Protected Areas has established the Strategic Framework for Protected Area Capacity Development 2015-2025 (SFCD), which provides information, methods \& tools in four programmes: professionalization, local communities, enabling \& evaluation.

The diversity of recognized managers \& stewards of protected areas has widened to include indigenous peoples, local communities, civil society organizations \& private owners. The specific capacity needs \& contributions of these groups are poorly understood $\&$ addressed.

\section{Key recommendations}

Strategic planning within protected areas should include methods for the co-development of the capacity of individuals, organizations \& wider society, \& should be designed to account for local political, economic \& cultural facilitating environments.

Responsible protected area organizations should define a set of core competencies for all professional levels \& adopt a competency-based approach to their capacity building.

Organizations should access available open-source competency resources \& adapt them to their specific needs.

Responsible protected area organizations should actively \& cooperatively engage with the SFCD framework \& the associated resources \& support.

Capacity building methods specific to indigenous peoples, local communities, civil society organizations \& private owners need to be researched \& communicated.

TABLE 2 Key discussions and recommendations in relation to the building of capacity for community engagement and rights-based governance in sub-Saharan Africa.

Key discussion points

The conservation \& sustainable management of natural resources requires communities with a shared vision of how goals can be achieved in an equitable \& mutually beneficial way.

Community engagement will be truly effective only if it is long-term (beyond project duration) \& achieves the required community change though a process of coordinated evolution.

Communities effectively engaged in conservation \& natural resource management have:

People with positive views of natural systems \& who are involved in their management.

Equitable \& supportive community organizations with long-term systems in place for governance, finance, benefit sharing \& membership.

Vertical linkages between local organizations \& external agencies/NGOs that ensure coherent policy development $\&$ reduce financial risk.

The engagement, education \& involvement of young people within communities are essential for the sustainability \& mainstreaming of community-based conservation \& resource management.

A community, no matter how engaged, is still subject to a range of local contexts that can inhibit or facilitate its conservation \& resource management actions. Many of these will involve local government organizations \& individuals.
Key recommendations

Information about the characteristics of successful communitybased conservation \& engagement initiatives should be collated $\&$ disseminated using suitable platforms.

Community conservation initiatives must build capacity in community engagement that aims to mainstream conservation $\&$ resource management throughout an engaged community.

Research should be conducted to develop indicators that measure the extent to which community engagement has been developed (in addition to the attainment of ecological goals).

Information about the characteristics of successful initiatives involving next generation engagement should be collated \& disseminated.

Community-based conservation initiatives should ensure that capacity building for local government is also a key focus. 
TABLE 3 Key discussions and recommendations in relation to the building of capacity to develop effective leadership and strong organizations within the conservation sector of sub-Saharan Africa.

Key discussion points
Many leaders of conservation organizations have considerable
demands put upon them. The isolation \& burden that many feel
could be overcome by the development of a professional body for
African conservation leaders. This would facilitate communi-
cation, sharing of best practice, \& capacity building in appro-
priate skills.

Workshop delegates identified 7 key characteristics of impactful \& effective organizations: (1) a culture \& values shared by all staff, (2) a clear guiding strategy \& long-term vision, (3) accountability to constituents, (4) strong leadership \& governance, (5) managers who put their staff first, (6) the ability to learn from experience \& employ adaptive management, \& (7) systems to seek strategic partnerships pro-actively.

The relationship between NGOs \& funders can be strained by the high levels of oversight \& capacity required simply to administer \& comply with project grants. There can also be pressure upon a small organization's vision, which may have to embrace new areas of work to access funds. Smaller organizations can also feel that they are merely agents to execute the project activities of the lead group rather than true partners.

Monitoring \& evaluating the impact of organizational \& leadership capacity building are vital processes but are difficult to achieve.

The key findings from a major published study (Maliasili Initiatives \& Well Grounded, 2015) were presented \& discussed.
Key recommendations

A professional body for African conservation leaders should be established.

Organizations should allow staff structured leave from everyday duties to develop their leadership capacity.

Leadership development should be extended beyond the formal higher education system \& short-term training.

Leadership development should address the need to create functioning teams \& facilitate exposure to external conservation initiatives.

Recognition (through awards, for example) can have a significant impact on an individual's professional growth. Such schemes should be developed within \& between African nations.

Organizations should:

Institutionalize their vision, \& implement it through a clear \& accessible strategy.

Avoid mission drift \& be able to say no to projects, funding, groups, etc.

Have transparent fundraising strategies focused on the vision (not funding body evaluation).

Proactively share \& effectively communicate organizational lessons learned.

Invest more in effective internal \& external communication.

Build leadership capacity at all organizational levels.

Employ novel \& creative ways to build organizational capacity.

Conservation funding bodies should adapt their granting models directly towards smaller organizations \& avoid pressuring local visions.

Conservation organizations should proactively influence the donor agenda through increased lobbying \& creating space for dialogue.

Conservation organizations should build collaborative business skills (with help from the private sector) to ensure sustainable funding streams \& avoid donor-dependency.

Conservation organizations should improve internal capabilities \& funding to measure capacity (or engage social science partners), \& create baselines against which future development of capacity can be measured.

Conservation \& civil society organizations should review \& improve their partnership \& investment models.

Conservation \& civil society organizations should seek \& support new approaches to leadership development.

Conservation \& civil society organizations should promote dialogue around fundamental issues of accountability, constituencies \& sustainability. 
TABLE 4 Key discussions and recommendations in relation to the building of professional e-learning to support the conservation and resource management sectors of sub-Saharan Africa.

Key discussion points

A range of universities \& training institutes in Africa currently provide tertiary-level conservation courses relevant to pre-career \& mid-career practitioners. However, the supply of courses is not currently keeping pace with demand, \& the cost of such courses is rising in many parts of Africa. Online courses can be a costeffective, readily accessible alternative to more conventional learning systems.

Whilst e-learning offers a range of opportunities for capacity building in the conservation sector, a number of challenges remain for providers.

Relevant institutions often require considerable organizational development to increase their e-learning provision.
Key recommendations

A major gap analysis should be undertaken to understand the key areas of conservation capacity development that would most benefit from e-learning approaches, \& to ensure course provision is based on evidence of prioritized needs within the sector.

E-learning providers should:

Ensure interactions between students \& academics, devise courses that include practical sessions, \& safeguard against cheating.

Monitor \& reduce course drop-out rates.

Develop capacity to measure the quality \& impact of course designs \& delivery.

Lever available (and increasing) open educational resources.

E-learning institutions should:

Ensure appropriate \& long-term information \& communications technology \& internet infrastructure investment.

Develop their quality assurance capacity.

Provide development \& support for staff.

Take advantage of mobile technologies \& increased penetration of these technologies in Africa's rural communities.

E-learning courses to support professional \& community conservation should focus course content, methodologies \& marketing strategies towards identified key audiences, \& address key issues in the widening participation agenda (e.g. age, gender, disability).

Conservation organizations should work with e-learning course developers/providers to create relevant material for life-long learning across all structural levels. evaluate such a community network, an assessment of the success and impact of these activities, and hence the conference, will be published in 2018 .

Delegates also noted that a number of dominant issues were common to all the conference workshop discussions. Firstly, in the face of ongoing and rapid socio-environmental change in sub-Saharan Africa there needs to be a greater sense of urgency in the development of capacity building activities by organizations, responsible agencies and donors. In these groups, capacity building should be recognized and prioritized as one of the most urgent conservation issues of the 21st century (Rodríguez et al., 2006). Secondly, there is a need to scale-up current capacity building activities significantly in terms of their number, focus and geographical/social footprint. Thirdly, notwithstanding the need to develop novel cost-efficient capacity building methodologies (and associated evaluation metrics), the future of capacity building for conservation will probably be best served by integrating new methods with more established activities (Washington et al., 2015). Fourthly, given the broad suite of social, cultural and economic contexts found across sub-Saharan Africa, there is a need to move away from one-size-fits-all approaches. The issues can be addressed only through increased cross-sectoral collaboration and information exchange. Ultimately, closing the gap between capacity need and capacity provision in the 
region will be achieved only through multi-partner capacity initiatives and networks.

\section{Acknowledgements}

We thank the following organizations for their generous support of the conference: Critical Ecosystem Partnership Fund (financial support for delegates), Organisation Internationale de la Francophonie (simultaneous translation into French), East African Wild Life Society (meeting facilities for the organizing committee), and Fauna \& Flora International (staff time and delegate funding). The conference was also supported by conceptual input from Brett Bruyere and Jim Barborak (Colorado State University), Francis Staub (Biodiversité Conseil), Fred Nelson (Maliasili Initiatives), Robyn Dalzen (Conservation International) and Andrea Santy (Russell E. Train Education for Nature Program, WWF).

\section{Author contributions}

MJO drafted the article and developed the core concepts. $\mathrm{ON}$ and KHF helped develop the core concepts and made extensive comments on early drafts. All other authors made comments on early drafts.

\section{References}

Aderinoye, R., Siaciwena, R. \& Wright, C.R. (2009) A snapshot of distance education in Africa. International Review of Research in Open and Distributed Learning, 10, 1-4.

Agrawal, A. \& Gibson, C.C. (1999) Enchantment and disenchantment: the role of community in natural resource conservation. World Development, 27, 629-649.

Ambalam, K. (2014) Challenges of compliance with multilateral environmental agreements: the case of the United Nations Convention to Combat Desertification in Africa. Journal of Sustainable Development Studies, 5, 145-168.

Appleton, M.R. (2015) Towards Strengthened Conservation Planning in South-Eastern Europe: Capacity Development Needs and Priorities for Nature Conservation in South-Eastern Europe. IUCN, Gland, Switzerland, and Belgrade, Serbia.

Armitage, D. (2005) Adaptive capacity and community-based natural resource management. Environmental Management, $35,703-715$.

Barnes, M.D., Craigie, I.D., Harrison, L.B., Geldmann, J., Collen, B., Whitmee, S. et al. (2016) Wildlife population trends in protected areas predicted by national socio-economic metrics and body size. Nature Communications, 7, 12747, http://dx.doi.org/ 10.1038 /ncomms12747.

Beresford, A.E., Eshiamwata, G.W., Donald, P.F., Balmford, A., Bertzky, B., Brink, A.B. et al. (2013) Protection reduces loss of natural land-cover at sites of conservation importance across Africa. PLoS ONE, 8(5), e65370.

Bertzky, B., Corrigan, C., Kemsey, J., Kenney, S., Ravilious, C., Besançon, C. \& Burgess, N. (2012) Protected Planet Report 2012: Tracking Progress towards Global Targets for Protected Areas. IUCN, Gland, Switzerland, and UNEP-WCMC, Cambridge, UK.
BirdLife International (2013) State of Africa's Birds 2013: Outlook for Our Changing Environment. BirdLife International Africa Partnership, Nairobi, Kenya.

Black, S.A., Groombridge, J.J. \& Jones, C.G. (2011) Leadership and conservation effectiveness: finding a better way to lead. Conservation Letters, 4, 329-339.

Borrini-Feyerabend, G., Dudley, N., Jaeger, T., Lassen, B., Pathak Broome, N., Phillips, A. \& Sandwith, T. (2013) Governance of Protected Areas: From Understanding to Action. Best Practice Protected Area Guidelines Series No. 20, IUCN, Gland, Switzerland.

Brightwell, A. \& Grant, J. (2013) Competency-based training: who benefits? Postgraduate Medical Journal, 89, 107-110.

Bruinsma, J. (ed.) (2009) The Resource Outlook to 2050: by How Much Do Land, Water and Crop Yields Need to Increase by 2050? Expert Meeting on How to Feed the World in 205o. Economic and Social Development Department, Food and Agriculture Organization of the United Nations, Rome, Italy.

Bruyere, B.L. (2015) Giving direction and clarity to conservation leadership. Conservation Letters, 8, 378-382.

Burke, J. (1989) Competency Based Education and Training. Routledge, Abingdon, UK.

Burnside, C. \& Dollar, D. (2004) Aid, Policies, and Growth: Revisiting the Evidence. Policy Research Working Paper Series 3251. World Bank, Washington, DC, USA.

Coad, L., Leverington, F., Knights, K., Geldmann, J., Eassom, A., KApos, V. et al. (2015) Measuring impact of protected area management interventions: current and future use of the Global Database of Protected Area Management Effectiveness. Philosophical Transactions of the Royal Society B, 370, 20140281.

Craigie, I.D., Baillie, J.E.M., B almford, A., Carbone, C., Collen, B., Green, R.E. \& Hutton, J.M. (2010) Large mammal population declines in Africa's protected areas. Biological Conservation, 143, 2221-2228.

FAO (Food and Agriculture Organization of the United Nations) (2011) Women in Agriculture: Closing the Gender Gap for Development. FAO, Rome, Italy.

Furuholt, B. \& Kristiansen, S. (2007) A rural-urban digital divide? Regional aspects of internet use in Tanzania. Journal on Information Systems in Developing Countries, 31, 1-15.

Guerrero, A.M., McAllister, R.R.J., Corcoran, J. \& Wilson, K.A. (2013) Scale mismatches, conservation planning, and the value of social-network analyses. Conservation Biology, 27, 35-44.

Han, X., Josse, C., Young, B.E., Smyth, R.L., Hamilton, H.H. \& BOWLES-NEWARK, N. (2016) Monitoring national conservation progress with indicators derived from global and national datasets. Biological Conservation, in press, http://dx.doi.org/10.1016/j.biocon. 2016.08.023.

He, W., Goodkind, D. \& Kowal, P. (2016) An Aging World: 2015. U.S. Census Bureau, Washington, DC, USA.

Henson, A., Williams, D., Dupain, J., Gichohi, H. \& Muruthi, P. (2009) The Heartland Conservation Process: enhancing biodiversity conservation and livelihoods through landscape-scale conservation planning in Africa. Oryx, 43, 508-519.

Hockings, M., Stolton, S., Leverington, F., Dudley, N. \& Courrau, J. (2006) Evaluating Effectiveness: A Framework for Assessing Management Effectiveness of Protected Areas. IUCN, Cambridge, UK.

IUCN (2015) Strategic Framework for Capacity Development in Protected Areas and Other Conserved Territories 2015-2025. IUCN, Gland, Switzerland. Http://www.biopama.org/sites/default/files/ content/documents/sfcd_final_july_2015.pdf [accessed 12 October 2016]. 
Jones, K.R. (2003) Multilateral environmental agreements in Africa: efforts and problems in implementation. International Environmental Agreements, 3, 97-135.

Kothari, A., Corrigan, C., Jonas, H., Neumann, A. \& Shrumm, H. (eds) (2012) Recognising and Supporting Territories and Areas Conserved by Indigenous Peoples and Local Communities: Global Overview and National Case Studies. Technical Series No. 64. Secretariat of the Convention on Biological Diversity, Montreal, Canada.

Lampietti, J. \& Subramanian, U. (1995) Taking stock of national environmental strategies. Environmental Management Series Paper No. o1o. World Bank, Washington, DC, USA.

Leverington, F., Costa, K.L., Courrau, J., Pavese, H., Nolte, C., Marr, M. et al. (2010a) Management Effectiveness Evaluation in Protected Areas-A Global Study. 2nd edition. The University of Queensland, Brisbane, Australia.

Leverington, F., Costa, K.L., Pavese, H., Lisle, A. \& Hockings, M. (2010b) A global analysis of protected area management effectiveness. Environmental Management, 46, 685-698.

Lewis, D. (2002) Civil society in African contexts: reflections on the usefulness of a concept. Development and Change, 33, 569-586.

Manthai, W. (2009) The Challenge for Africa. Anchor Books, New York, USA.

Maliasili Initiatives \& Well Grounded (2015) Strengthening African Civil Society Organizations for Improved Natural Resource Governance and Conservation. Maliasili Initiatives and Well Grounded, Underhill, USA, and London, UK.

Manolis, J.C., Chan, K.M., Finkelstein, M.E., Stephens, S., Nelson, C.R., Grant, J.B. \& Dombeck, M.P. (2009) Leadership: a new frontier in conservation science. Conservation Biology, 23, $879-886$

McKee, J.K., Sciulli, P.W., Fooce, C.D. \& Waite, T.A. (2004) Forecasting global biodiversity threats associated with human population growth. Biological Conservation, 115, 161-164.

Mittermeier, R.A., Turner, W.R., Larsen, F.W., Brooks, T.M. \& GASCON, C. (2011) Global biodiversity conservation: the critical role of hotspots. In Biodiversity Hotspots: Distribution and Protection of Conservation Priority Areas (eds F.E. Zachos \& J.C. Habel), pp. 3-22. Springer, Berlin, Heidelberg, Germany.

Múller, E., Appleton, M.R., Ricci, G., Valverde, A. \& Reynolds, D. (2015) Capacity development. In Protected Area Governance and Management (eds G.L. Worboys, M. Lockwood, A. Kothari, S. Feary \& I. Pulsford), pp. 251-290. ANU Press, Canberra, Australia.

Myers, N., Mittermeier, R.A., Mittermeier, C.G., Da Fonseca, G.A.B. \& KenT, J. (2012) Biodiversity hotspots for conservation priorities. Nature, 403, 853-858.

Ozor, N., Acheampong, E.N. \& Ayodotun, B. (2016) Review of policies, legislations and institutions for biodiversity information in sub-Saharan Africa. International Journal of Biodiversity and Conservation, 8, 126-137.

Pan, S., Dangal, S.R.S., TAO, B., YAnG, J. \& Tian, H. (2015) Recent patterns of terrestrial net primary production in Africa influenced by multiple environmental changes. Ecosystem Health and Sustainability, 1, 1-15.

Perrings, C. \& Halkos, G. (2015) Agriculture and the threat to biodiversity in sub-Saharan Africa. Environmental Research Letters, 10, 1-10.

Rio+2o PORTAL (2016) Http://riozo.net/en/propuestas/resolutionon-a-human-rights-based-approach-to-natural-resourcesgovernance [accessed 12 October 2016].

Rodríguez, J.P., Rodríguez-Clark, K.M., Oliveira-Miranda, M.A., Good, T. \& Grajal, A. (2006) Professional capacity building: the missing agenda in conservation priority setting. Conservation Biology, 20, 1340.
Secretariat of the Convention on Biological Diversity (2014) Global Biodiversity Outlook 4. SCBD, Montréal, Canada. Senge, P.M. (2006) The Fifth Discipline: The Art \& Practice of the Learning Organization. Doubleday, New York, USA.

ShafiKa, I. \& Hollow, D. (2012) The e-Learning Africa 2012 Report. Http://www.elearning-africa.com/pdf/report/ela_report_2012.pdf [accessed 12 October 2016].

Steiner, A., Kimball, L.A. \& Scanlon, J. (2003) Global governance for the environment and the role of Multilateral Environmental Agreements in conservation. Oryx, 37, 227-237.

Stolton, S. \& Dudley, N. (2010) Arguments for Protected Areas: Multiple Benefits for Conservation and Use. Earthscan, London, UK.

Stuart, S.N. \& Adams, R.J. (1990) Sub-Saharan Africa and Its Islands: Conservation, Management and Sustainable Use. Occasional Papers of the IUCN Species Survival Commission 6. IUCN, Gland, Switzerland.

Stuart, S.N., Chanson, J.S., Cox, N.A., Young, B.E., Rodrigues, A.S.L., Fischman, D.L. \& Waller, R.W. (2004) Status and trends of amphibian declines and extinctions worldwide. Science, 306, 1783-1786.

Turral, H., Burke, J. \& Faurès, J.-M. (2011) Climate Change, Water and Food Security. FAO Land and Water Division Report 36. Food and Agriculture Organization of the United Nations, Rome, Italy.

UNDESAPD (United Nations, Department of Economic and Social Affairs, Population Division) (2015) World Population Prospects: The 2015 Revision, Key Findings and Advance Tables. UNDESAPD Working Paper No. ESA/P/WP.241. United Nations, New York, USA.

UNEP (United Nations Environment Programme) (2010) State of Biodiversity in Africa. Regional Office for Africa, UNEP, Nairobi, Kenya.

UneP-WCMC (United Nations Environment ProgrammeWorld Conservation Monitoring Centre) (2016) The State of Biodiversity in Africa: A Mid-term Review of Progress Towards the Aichi Biodiversity Targets. UNEP-WCMC, Cambridge, UK.

UNiSDR (United Nations International Strategy for Disaster Reduction) (2016) Terminology. Https://www.unisdr. org/we/inform/terminology [accessed 12 October 2016].

Vasudev, D., Kumar, A. \& Karanth, K.U. (2015) Enhancing conservation science capacity in India: first decade of the Master's programme in wildlife biology and conservation. Oryx, 49, 16.

Washington, H., Baillie, J., Waterman, C. \& Milner-Gulland, E.J. (2015) A framework for evaluating the effectiveness of conservation attention at the species level. Oryx, 49, 481-491.

Western, D. (2003) Conservation science in Africa and the role of international collaboration. Conservation Biology, 17, 11-19.

Whittle, S., Colgan, A. \& Rafferty, M. (2012) Capacity Building: What the Literature Tells Us. The Centre for Effective Services, Dublin, Ireland.

Wilder, L. \& Walpole, M. (2008) Measuring social impacts in conservation: experience of using the Most Significant Change method. Oryx, 42, 529-538.

World BAnk (2009) Accelerating Catch-up: Tertiary Education for Growth in Sub-Saharan Africa. World Bank, Washington, DC, USA.

WWF (2016) About Global Ecoregions. Http://wwf.panda.org/about_ our_earth/ecoregions/about/ [accessed 12 October 2016].

\section{Biographical sketches}

The authors comprised a team of African and international conservationists who helped to develop and deliver the 2015 Nairobi capacity building conference. Collectively they represent key conservation organizations, agencies, institutes and civil society organizations for which 
capacity building and evaluation is a key issue. They are committed to finding sustainable and context-relevant solutions to this difficult and urgent task. MARK O'CONNELL is a conservation scientist who has led three regional meetings on capacity building. These have been designed to identify key common issues, facilitate discussion of potential solutions, and learn from successful initiatives. OLIVER NASIRWA has worked on a wide diversity of conservation projects in Africa, including building regional capacity for environmental monitoring programmes. MARIANne CARTER leads a team engaged in efforts to develop conservation leadership skills globally. 